\title{
A Discussion of Relevant Religious Teachings from Islam and Christianity to the COVID-19 Crisis
}

\author{
Irfan Raja ${ }^{1}$, Ruth Dowson ${ }^{2}$, Abdul B. Shaikh ${ }^{3}$, and Tariq El-Hadary ${ }^{4}$
}

\begin{abstract}
The Coronavirus crisis has undoubtedly changed the landscape of the world. The pandemic has radically changed the way of life of most of the seven billion people in the global community. In the past, people living in uncertain times bave sought solace and comfort in God, through the medium of faith. This paper considers historical perspectives of past epidemics and pandemics, comparing and contrasting the themes that arise through relevant religious teachings of Islam and Christianity, with the aim of identifying sources of consolation to contemporary adherents in the current crisis.
\end{abstract}

Keywords: Religious teachings; COVID-19 crisis; Islam; Christianity

\section{Introduction}

During the first few months of 2020, the Coronavirus, COVID-19, spread worldwide; sixteen months later, the toll of Coronavirus victims had risen to almost 150 million cases, with over 3.1 million deaths (Worldometers, 2021). Unfortunately, the virus is easily transmitted through close contact, which initially rendered health authorities around the world almost powerless to cope with the large number of cases. Gaythorpe et al (2020) suggest that risk-based prevention and control tactics to improve epidemiological examination, case managing, and preclusion in high-risk populations will help to control the pandemic. By early 2021, whilst the positive impact of vaccination programs was being experienced in some countries, vaccines were in short supply and still awaited elsewhere, as the world anticipates a third wave of the virus.

The Coronavirus crisis has undoubtedly changed the landscape of the world. The pandemic has radically changed the way of life of most of the seven billion people in the global community. Unprecedented numbers of people have been and continue to be confined to their homes for indefinite periods. Across the world, as many governments have imposed lockdowns to save lives, death tolls continue to rise and increasing numbers of people are infected daily with COVID-19. Fear, anxiety, stress, poverty, and living with uncertainty, continue to grip the lives of billions. In the past, people living in uncertain times have sought solace and comfort in God, through the medium of faith. This paper considers historical perspectives of past epidemics and pandemics, comparing and

\footnotetext{
${ }^{1}$ Irfan Raja, Instructor at Brentwood Open Learning College, Independent Researcher, Author at Daily Sabah and Asia Times, United Kingdom. E-mail: irfan.journalist@gmail.com.

${ }^{2}$ Rev. Ruth Dowson, Senior Lecturer, Leeds Beckett University, United Kingdom. E-mail: R.dowson@leedsbeckett.ac.uk.

${ }^{3}$ Abdul B. Shaikh, Lecturer in Arabic \& Islamic Studies, University of Leeds, United Kingdom. E-mail: a.b.shaikh@leeds.ac.uk.

4 Tariq El-Hadary, Assistant Professor, School of Applied Sciences, Department of Translation and Interpreting, Istanbul Gelisim University, Turkey. E-mail: Thmelhadary@gelisim.edu.tr.
} 
contrasting the themes that arise through relevant religious teachings of Islam and Christianity, with the aim of identifying sources of consolation to contemporary adherents in the current crisis.

A 2014 global survey conducted by Pew Research on 'Belief in God' concluded that the majority of people agreed that religious belief underpins values and moral life. More recently, a 2020 Pew Research survey across 34 countries revealed that for most people, religion (62\%), God (61\%), and prayer (53\%) "plays an important role in their lives" (Tamir et al., 2020). We note that there are varying levels of faith across different countries and continents. For instance, in the United Kingdom, most surveys conducted in the last ten years reveal an emerging pattern showing that the twin forces of secularism and atheism have enjoyed a surge in growth since the 1980s (Phillips et al., 2018; Jones, 2015). In the United States of America, there is a significant rise in people seeking out a 'higher being' or accepting the existence of an absolute power that may or may not be 'God' as described in the Bible, contrasting with more traditional views (Hrynowski, 2019; Lipka and Hackett, 2017).

Despite Western nations becoming increasingly filled with doubt and scepticism however, Goodhew highlights the rapid expansion of religion in parts of South America, Asia and Africa (Goodhew, 2012: 17); this growth applies to both Islam and Christianity alike. Record numbers of people identify themselves as Muslims (Pew Research, 9 August 2012), and by 2026, Islam will have become the world's largest religion (Lipka and Hackett, 2017), surpassing Christianity in the process (ibid). Trimble and Austin (2020) list the world's ten most religious countries; eight of those listed are Islamic, whilst Israel and India rank first and third, respectively.

Throughout history, in uncertain times, human beings have turned towards their Creator Allah / God. The COVID-19 crisis has reintroduced the idea of repentance and turning towards God, as in the past, in times of disaster, uncertainty, and disease. Many Western scholars acknowledge the idea of turning towards God in pressing times, seeking comfort, spiritual rebuilding, repentance, prayer, and guidance to overcome the crisis (Guntzelman, 2011; Hindson, 1999; Kelly et al. (2002). Kelly et al. observe that throughout the history of Islam and Christianity, "Both Muslims and Christians thought that disease could be sent by their God. Christians often encouraged prayer, the repenting of sins and fasting rather than treatment" (Kelly et al., 2002, p.45-47).

In 2020 the Coronavirus crisis has motivated many interfaith groups to come together for prayers and repentance. In the West, and in particular, in the United States of America, sections of the mainstream media have published articles that direct attention to this turn to God (Cheng, 2020; Perkins, 2020). This paper intends to highlight the narrative of relevant religious texts and practices, asserting their application in the Coronavirus crisis. It considers how adherence to the faiths of Islam and Christianity can help to foster health, and asks whether observing their divine principles and precepts could help to combat disease. The following sections are designed to provide a contextual framework for discussion of sacred Islamic and Christian texts and rituals as they relate to the Coronavirus tragedy.

Notably, Islamic teachings put trust in divine rules that are regarded as essential to health and to the treatment of disease. For example, cleanliness, purification of the body and soul, and charity, are fundamental principles mentioned in the Qur'an (Q.2:222, Q.74.4) and in the Islamic prophetic traditions (hadith).

\section{History of Pandemics}

A pandemic is defined as a disease that affects people over a wide area. An epidemic might engulf a whole community, but a pandemic is much more widespread - and in the case of the Coronavirus, it 
is global. Over the course of human history, the world has been struck by many pandemics and epidemics that have claimed numerous lives; some have been successfully confronted and eliminated, whilst others have simply run their course.

In the year 735, (Farris, 1985) an outbreak of Japanese smallpox appeared in Tokyo and spread to neighboring countries, killing about one million people within two years. The most fatal disease in history was the bubonic plague, called the 'black death' (Gottfried, 1983) because it formed black spots on the skin. This plague spread between 1347 and 1351, causing the death of nearly 200 million people around the world. It is believed to have originated in or near China, then moved to Italy and spread through the rest of Europe, and on to other countries across the world. Three centuries later, between 1647 and 1652, the plague swept through Seville, killing about 76,000 people, or about a quarter of the population of the Andalusian region (Bell, 2019). When smallpox appeared in 1520 $\mathrm{AD}$, it claimed the lives of 56 million people. Between 1665 and 1666, the Great (Bubonic) Plague in London killed some $20 \%$ of the city's population. In 1855, an advanced type of plague known as the 'third epidemic' appeared in Yunnan Province of China, to spread later to all inhabited continents of the world, killing approximately 12 million people (Sweet, 2014), whilst cholera killed one million people around the world between 1817 and 1923.

From 1889 to 1890, the Russian flu epidemic killed one million people, almost the same number of deaths caused by the Asian flu that appeared in China in 1956 (Ewing, 2017). The influenza pandemic of 1918 to 1919, known as the "Spanish flu", was the most serious health disaster in modern history (Honigsbaum, 2013). This influenza broke out while the First World War was still raging, and a pandemic swept through the population in three successive waves (He et al., 2013): the first was in the spring of 1918; the second - the deadliest, which killed 90 percent of the total victims - was in the fall of 1918; and the third was from the winter of 1918 to the spring of 1919. Historians and epidemiologists estimate death rates ranging from 2.5 percent to five percent of the world's population, or approximately 50 to 100 million deaths. The Spanish flu pandemic was five to ten times more deadly than World War I.

In recent times, Swine flu (Khanna et al, 2009) appeared in 2009-2010, in the United States and Mexico, and spread to all countries of the world, killing some 200,000 people. Between 2014 and 2016, the Ebola virus spread across several African countries and to some other areas, killing over 11,000 people. The spread of the SARS virus killed 774 people, while MERS has killed at least 828 people since 2012. As for the Coronavirus, COVID-19, which originated in China in December 2019, the number of infections worldwide (by the end of August 2020) reached 25,187,847, with more than 847,000 confirmed deaths (Worldometers, 2020). By the end of April 2021, the figures were $149,388,450$ cases and 3,150,786 deaths worldwide (Worldometers, 2021).

\section{Historical Perspectives}

The following section considers the historical perspectives of Islam and Christianity through the lens of pandemics.

\section{Historical Perspectives of Islam: Amwas plague}

The spread of the plague in the Levant (Greater Syria), which began in the town of Amwas, challenged the ability of the young Islamic state led by Umar ibn al-Khattab (the second of the 'rightly guided' caliphs Rashidun caliphate) to deal with a pandemic that went on to claim the lives of thousands of Muslims. Historical accounts of this plague present different numbers of victims (Waqidi, 2004; Tabri, 1967; Ibn Kathir, 2010), but deaths ranged from fifteen to twenty thousand, including senior 


\section{A Discussion of Relevant Religious Teachings from Islam and Christianity to the COVID-19 Crisis}

leaders. In 17AH, Umar ibn al-Khattab had wanted to visit the Levant (Greater Syria) for a second time, so he travelled with his companions to Sargh on the borders of the Hijaz and the Levant. There he met Muslim leaders who told him that the plague was continuing its spread across the Levant, so Umar made up his mind to go back home.

After Umar's departure, the Amwas plague swept through the Levant (Waqidi, 2004; Tabri, 1967; Ibn Kathir, 2010). This epidemic did not weaken until after Amr bin Al-Aas took over and became the guardian of the region. Amr bin Al-Aas summoned the people and put forward a plan to escape the plague, ordering the people to leave their land for the mountains. He thought that leaving the polluted environment would end the disaster. The Caliph did not comment on Amr's actions, which was interpreted that Amr's plan was acceptable. At that time it was thought that viruses could be transmitted through the air, through infected people coughing and sneezing.

Abdur-Rahman bin Auf said, 'I have heard Allah's Messenger (P.B.U.H) saying, "If you hear about it (an outbreak of a plague) in a land, do not go to it; but if the plague breaks out in a country where you are staying, do not run away from it." (Al-Bukhari, 2003). The Companions' views towards this idea of banning travel from an infected land differed; while Umar wanted Abu Ubaidah to leave the land in which the plague occurred, Abu Ubaidah apologized and remained with the Muslims. The Caliph's idea (Alsalabi, 2005) was to travel with Muslims from the infected land (where there is an abundance of water and swamps) to mountainous land. After they met in Sargh, and they heard the hadith of Abd al-Rahman bin Auf that prohibited going out, Umar wrote to Abu Ubaidah urging him to leave the infected land. Umar returned to Medina upon the advice of the Companions.

In summary, from an Islamic perspective, both remaining in and leaving an infected land are allowed. For those who are in the area of an epidemic and infected, there is no point in leaving, because this may cause the disease to be transmitted to healthy people. However, if they are not infected, people are permitted to leave the area, provided that some remain. If everybody leaves, who will take care of the sick? Umar ibn al-Khattab dealt with this plague with utmost caution, as he and those with him did not enter the Levant, and he tried to extract those who recovered. The Caliph's decisions to evacuate people from the affected areas and go to the mountains enabled him to contain the crisis, but at the same time sparked an argument among the Companions.

Ibn Khaldun (1989), who himself suffered from the plague that killed his parents and teachers, was of the opinion that air pollution was the main cause of the Amwas plague. Ibn Khaldun suggested that if air, which is essential to human life, is polluted, then diseases may occur; and if air pollution is strong, the disease will pervade the lungs. Ibn Khaldun notes the negative impact of the condensed urban nature of cities, which results in poor ventilation, which can negatively impact the personality and mental health of the individual. Ibn Khaldun suggests a solution, which is to leave areas or spaces between buildings to allow the free passage of air and to facilitate the exit of 'corrupt' air. Dealing with pandemics and epidemics was an important indicator of the extent of the state's strength and the management of its leaders. Historians such as Bulaqteeb (2002) tell us that, in the face of the leprosy epidemic that struck the territories of his country, Caliph Yaqoub al-Mansur al-Mawhid created lanes outside the metropolitan areas in which the injured were gathered, known as the "leprosy neighbourhoods" in order to reduce transmission.

Kelly et al observe that, "The Islamic hadith instructed doctors to try to cure patients: 'Oh servants of Allah, use the medicine. Allah has not created pain without a remedy for it” (2002, p.45-47). Kelly et al (2002) go on to describe an example from Cairo hospitals in 1283, where patients received financial assistance on leaving the hospital, to enable them to stay off work until they were fully 
healed. In the same vein, early Muslim scientists, mathematicians, jurists and theologians laid the foundations of surgery and medical theories that are still valid and relevant today (Al-Khalili, 2018). For example, early Muslim scientists such as Ibn Al Durayhim and Ibn-Sina (Avicenna) successfully used the organs of animals, birds' wings and pigeons' blood to advance the healing process and to provide a cure for certain maladies (Edriss et al., 2017, pp.223-228).

These examples from Islamic history show the longstanding nature of some of the interventions that have been introduced during the COVID-19 pandemic, such as the frequent washing of hands, maintaining social distancing, ensuring that fresh air is allowed to flow within buildings, and allowing outdoor exercise and gatherings. The next section considers the historical experiences of pandemics from a Christian perspective.

\section{Historical Perspectives of Christianity}

In considering how Christian communities dealt with pandemics in the past, we begin with Biblical origins. The word 'plague' appears approximately one hundred times in the Christian Bible, primarily in the Old Testament. The most notable Old Testament plagues took place in Egypt and are central to the story of Moses. In the Bible, plagues were often sent as a result of the disobedience and idolatry of people. One example of such plague is found in Exodus 32:35: "Then the Lord sent a plague on the people because they made the calf - the one that Aaron made". In this instance, the plague has been sent by God to punish the people for their disobedience and idolatry in making and worshipping a golden calf.

Plagues are also mentioned in the New Testament. The apocalyptic book of Revelation describes a vision of the 'end of days' on Earth, and was written during a period when Christians were facing oppression in exile, and death. Revelation draws intense images of adversaries in an "eschatological conflict that will culminate in the victory of God and the final defeat of all evil" (Coogan, 2007, p.421). In this context, pandemics are perceived as being quite rare in human history (Harper, 2015, p.223). However, the period of early Christianity (in later antiquity), as practices and beliefs were developing, was a time considered by some to be the "age of pandemic disease" (Ibid.).

We begin by examining Christian experiences of pandemics in Roman times. This period began with the Antonine plague (smallpox) in the mid-160s CE, known as the first pandemic "in all of human history" (Ibid., p.223). This plague caused severe demographic repercussions, with long-term political and social consequences. This pandemic age ended with the Justinianic plague in the mid-6 $6^{\text {th }}$ Century (Bubonic plague, from rats) (Ibid.). In between these two plagues, as the Christian faith was making its way throughout the Roman Empire, the Cyprian plague of 249-270CE (Carragher and Pettigrew, 2019; Harper, 2015), probably originated in Ethiopia (Harper, 2015, p.233), moving from East to West. This plague had a considerable impact on Christianity in its infancy. The Cyprian plague was named after the Bishop of Carthage, who wrote in-depth about it from 249-270CE, and primarily affected the area around the Mediterranean and Northern Africa, especially the Nile basin and Alexandria (Ibid., p.227). This pandemic is thought by some to be hemorrhagic fever, whilst others have proposed that it was measles, or meningitis, bubonic plague, or acute bacillary dysentery (Ibid., p.245). Whatever the cause, this pandemic had significant social, political, economic, and cultural impacts (Ibid., p.224). People of all ages died, from babies to old people, and the adult population of Alexandria is estimated to have fallen by 62\% (Ibid., p.228), partly from the disease and partly from mass transit, as people sought to escape the ravages of the pandemic. 
The timing of this plague was important because during this period, Christians were spreading through the Roman Empire and their influence was growing over what were previously pagan communities. For example, pagan responses identified the Greek/Roman god Apollo as a protector against the plague, with sacrifices being made in Apollo's and Jupiter's temples to call down divine power for healing, and coins being minted and kept as protection (Ibid., p.225). Christians, however, were exhorted to remain steadfast in their faith, and the Christian community were noted for their charitable care of the sick, and orderly care and burial of their dead, despite the health risks posed by touching the bodies (Ibid., pp.228- 230). In addition, Mediterranean plagues prompted the development of Christian funerary rituals and "shaped the mortuary landscape of Christian communities" (Caraher \& Pettegrew, 2019, p.19) in this early stage of the faith.

In Carthage, Christian bishop Dionysius was forced to publish a response (probably a sermon) to the accusations that Christians were responsible for the war, drought, famine, and plague that had struck the region. Dionysius urged his fellow believers to endure the trial of plague (Harper, 2015, p.229) and noted that the plague had struck both pagans and Christians alike. Indeed, when pagans held a festival, the death toll included half the population of Neocaesarea in about 240CE (Ibid., p.238). In contrast, the miraculous healing powers of St Gregory, known as the 'Wonderworker', was viewed as overcoming demons, and led to the many conversions to Christianity (Ibid., pp.238-239). In Rome, this plague was seen as occurring "in times of unbearable anxieties and spiritual despair" (Ibid., p.240).

Harper suggests that such pandemic diseases are "capable of triggering profound change" (2015, p.249). In this instance, the dominant religious and cultural influences of paganism retreated, whilst Christian communities expanded rapidly (Ibid., p.250). Purpose-built meeting spaces were built to enable Christians to worship together, and Christian values and networks were embodied in new forms of community with shared rules of belonging. Harper concludes that the effects of this pandemic "undermined the stability of a religious culture that was embedded in society" (Ibid., p.258), replacing pagan practices with Christian spiritual life.

Since those early days of Christian experiences, there have been numerous pandemics. The Black Death 1347-1353 (Hays, 2009; Hays, 2005) was usually viewed by Christian communities as a punishment from God for sinful actions, whether corporately or individually. During the 19th Century, multiple cholera pandemics spread from the Indian subcontinent across Asia, mainly through Western military and colonial expansion (Echenberg, 2011, p.18). However, large gatherings of Hindu pilgrims aided the spread of the disease due to the poor quality of the temporary accommodation that was provided for them (Ibid., p.19). In 1833, a cholera epidemic that began at the Hajj subsequently led to 40 outbreaks elsewhere (Ibid., p.26). The Christian response to cholera pandemics by the Ethiopian Church was to organise religious processions through the streets, in order to call on God's mercy (Ibid., p.49). Unfortunately, this resulted in a wider spread of the disease.

In contrast with the Islamic approach that encouraged what we might view as proactive healthy practices, Christianity often viewed pandemics as punishment from God that needed to be responded to through penitent actions, some of which included gatherings that worsened the situation. There is a notable emphasis on care for the sick and the dead, at risk to the health of the carers, whilst Islamic practice encouraged the adoption of rituals and foods that promote health, as will be seen in the next section. The impact of pandemics on social and religious life in early Christianity led to growth in the number of followers, and spread the faith throughout the Roman world. 


\section{Religious Teachings}

This section considers the different religious teachings of Islam and Christianity to help followers living through pandemic times.

\section{Islam: Teachings in Times of Pandemics}

This section describes the treatment of disease and healthy living in the context of Islamic tradition, and in light of the Qur'an and Prophetic tradition. We explore the role and significance of the Prophet Muhammad's (P.B.U.H.) guidance on maintaining health and wellbeing, providing recommendations that may be used by people today coming to terms with life under the COVID-19 pandemic. We also explore narratives of how early Muslim scientists used religious texts to advance medicine and research. Sufi master, Ibn' Arabi, reflected on the connectedness of science and prayer, using the metaphor of branches of a river combining together as the path to God (Hakim, 2016). Early Muslim scientists had a close connection with the holy Qur'an; hence, Islam and science are united, like body and soul.

\section{The Importance of Health and Wellbeing in the Islamic Tradition}

The COVID-19 pandemic has undoubtedly changed the lives of billions around the world. However, little is known about what role religion can play in allaying the fears and anxieties of people of faith and no faith. This section aims to outline and discuss the role of Islamic teachings in providing valuable advice and guidance in terms of addressing the challenges and threats posed by pandemics.

Islam is the youngest faith within the Abrahamic traditions and like Christianity and Judaism is a source of divine inspiration, extolling the wisdom of none other than God. Judaism, Christianity, and Islam share common traits that are manifest in the sanctity of the preservation of life. The idea of preserving life at all costs has never resonated so much, especially in the Coronavirus Age (Elsanousi et al., 2020).

Islam, in the eyes of Muslims, is regarded as a complete system ordained by Allah's divine wisdom and providence, and thus encompasses every aspect of human life. The Islamic tradition undoubtedly teaches its adherents that all afflictions and diseases are trials from Allah. Diseases will afflict many people, and during their course, will mean the end of life for some, as Muslims believe that Allah has determined the lifespan of each and every living person (Peterson, 2020). Such tests are considered by Muslims to be a difficult part of life sent down by Allah as part of the divine plan for humanity, in order to see who is true in word, spirit, and deed to their lord (Q2:155. Peterson, 2020).

In terms of dealing with the prevalence and spread of Coronavirus, the Prophet Muhammad provides guidance and instruction on how to properly combat such diseases by declaring that one person should not harm another, and ensure that you are not harmed yourself (Elias; 2020; Peterson; 2020). This prophetic principle is underpinned by Sharia (Islamic law) that unequivocally declares that the preservation of religion and life are of paramount importance, as far as the welfare of the Muslim community is concerned (Elias, 2020; Peterson, 2020).

In such uncertain times, Islam provides some flexibility in performing religious obligations. For, example, if a Muslim cannot stand up to pray Salah (prayers) then dispensation has been given to pray sitting down. If a follower cannot fast during the hot summer months when the days are longer, then it is possible to fast in the winter months when the days are shorter. One aspect of Islam that gives greater credence to the vital preservation of life is that something that is generally prohibited in normal times becomes permissible in exceptional and very difficult circumstances. For example, if a 
person has not had food or drink, then the consumption of pork and alcohol becomes lawful, as Allah is not forcing his servants to choose between life and death (Peterson, 2020, Q2:185, Abou elFadl 1991).

\section{Mental Wellbeing: Patience and Thankfulness (Sabar and Shukar) in the Islamic Tradition}

The onset of COVID-19 has undoubtedly led to an increase in the number of people suffering from heightened anxiety, depression, and mental health issues (Kola, 2020). Mental health and wellbeing were being actively discussed by governments around the world prior to the onset of the pandemic, as current and future generations are at a greater risk of being affected in the future, and this has been exacerbated by the Coronavirus crisis (Ribero, 2020). The Islamic tradition emphasises patience, as it forms the foundation of the spiritual essence of faith (Azislam.com, 2020). Patience (sabr) in Islam epitomises endurance, and being mentally and spiritually strong, providing the believer with reassurance to remain steadfast and to withstand any issue or concern in a firm manner. In turn, if the believer can withstand tremendous trials and tribulations then, in turn, it makes him or her thankful (shukr) towards Allah, the Most Merciful and the Most Compassionate (Ibid., Q.2:177, Q.3.125, Q.39:10). The Islamic tradition also emphasizes the promotion of spirituality in the lives of Muslims on a daily basis. It is said that engaging in the remembrance of Allah (dhikr) provides reassurance to the heart (Ibid., 2020). Muslims are advised to recite the Qur'an daily to alleviate anxiety and depression; indeed, this gives the reader a sense of tranquillity and calmness, which in turn develops gratitude (shukar) for Allah as well as increasing levels of patience in life generally (Q.17:82, Q.16:69, Q.26:80, Azislam, 2020; Saged et al., 2020).

\section{Prophetic Guidance on Health and Wellbeing}

Islamic teaching on health and wellbeing are important in the age of Coronavirus, where those who are overweight or have pre-existing conditions such as diabetes, have a higher risk of suffering lifelong complications and death from the disease (Raleigh, 2020; Diabetes UK, 2020). The following sections summarise the prophetic guidance on healthy eating and living, which could improve physical health and mental wellbeing for followers, during the pandemic.

\section{Prophetic Guidance (Sunnah) on the Consumption of Natural Foods}

Olives 'Zaytoon': Olives have served a great purpose for civilisations past and present, and provide benefit in disciplines ranging from business to medicine (Mohamed, 2017). The Fig (Al-Tin) is the ninety-fifth chapter of the Qur'an that reveals the beneficial health effects of consuming olives and figs. The olive is praised in Q95:1 and Q24:35 by none other than Allah in the Holy Scripture and in the Prophetic Tradition (Hadith). (Stacey, 2018; Khan, 2019). In an age where obesity is increasing worldwide, due to people leading more sedentary lives and not eating healthily, governments and health specialists encourage people to adopt the Mediterranean diet (Fox et al., 2019; Bradford, 2015). It is said that this diet, which is based around the consumption of olive oil and figs, can have profound and dramatic effects on lowering cholesterol and blood pressure levels, and reducing the effects of diabetes (Ghaffar, 2018). The onset of Coronavirus has undoubtedly raised the risk of death in overweight and obese people substantially. The Prophetic guidance and the importance of the Mediterranean diet that includes olives and figs, contribute to combatting ailments and, in turn, potentially reducing the number of fatalities from Coronavirus (Ghaffar, 2018; Morrison, 2020; DiRenzo et al., 2020). 
The Fig: As mentioned, the fig is given special praise in the Qur'an in Chapter 95, alongside the olive (Q95:1). The fig, date, olive, pomegranate, grape, and banana are said to be the six fruits of paradise (Farhangi et al., 2014). The World Health Organisation (WHO) has suggested that figs could be used to treat diabetes, noting that in a 1998 study, participants who were asked to consume fig extracts experienced decreased glucose levels after consuming their evening meal. In addition, the consumption of fig extract reduced the need for higher doses of insulin in patients (Hatanaka and Caporusio, 2019).

Black Seed Oil: Nigella sativa has been regarded by Muslim and non-Muslim societies to be a medicinal cure for several ailments (Gali-Muhtasib, 2006; Yimer et al., 2019). In the Islamic tradition, the Prophet Muhammad (P.B.U.H.) stated that black seed heals every illness except death. The Biblical book of Isaiah $(25: 27)$ in the Old Testament refers to the harvesting of the oil from the black seed plant. A study was carried out in India with patients diagnosed with diabetes being given capsules containing black seeds, to be consumed daily for three months. At the end of the trial period, doctors noticed that fasting blood glucose and insulin resistance had reduced significantly. Medical professionals concluded that consuming black seed oil would be of benefit to those who are suffering from diabetes (Bamosa et al., 2010; Wong, 2020).

\section{Prophetic Guidance on Ghusl (ritual bath) and Wudhu (ablution)}

Islam emphasizes the importance of maintaining personal and public hygiene. Huseyin Ari, of the Turkish Directorate of Religious Affairs argues that if one is not in a state of purity, then one cannot entertain the idea of worshipping Allah (Sofuoglu, 2020). Muslims are aware of the need to be in a state of purity, especially prior to reciting the Qur'an and performing the five daily prayers (Burton, 1988; Aslan, 2020). In terms of Islamic purity laws, Muslims also must perform a ritual bath known as ghusl. The bath involves water being poured over the body at least three times, so that no part remains untouched. Muslims are advised to perform the bath on Fridays (Jummah), and prior to the two Eid prayers (Al-Munajjid, 2009; Aslan, 2020). At the height of the pandemic in Spring 2020, the UK Government advised the population to wash their hands regularly, as it was claimed that if the virus was present on the hands, then one could infect oneself unintentionally, by touching the nose, eyes, and mouth. Research from Australia suggests that, on average, humans touch their faces up to twenty-three times an hour (Kwok et al., 2015). Therefore, it is suggested that washing hands regularly would restrict the spread of the virus from person to person along with avoiding close contact with people outside their household (Rigby, 2020). In April 2020, Trevor Phillips argued that areas with a substantial number of Muslims, including Blackburn, Bradford, Luton, Rochdale, and Rotherham, did not become Coronavirus hotspots at that time due to Muslims performing ablution (wudhu) five times a day. Phillips stated that areas with large concentrations of Muslims generally suffer from socio-economic deprivation and therefore it would be expected that infection rates would be higher in those areas. Phillips suggested that the Islamic tradition that dictates that Muslims must wash before each of the five daily prayers and bathe every day could be a determining factor as to why rates of infection were low (Blanchard, 2020; Shah and Salam, 2020).

\section{Prophetic Guidance on Social Distancing in the Islamic Tradition}

At the start of the COVID-19 pandemic in 2020, the World Health Organisation issued guidance to combat the spread of the disease. One significant aspect of this guidance focussed on social distancing (WHO, 2020a; WHO, 2020b). There is Prophetic guidance on social distancing, as the Prophet asked his followers to keep to a reasonable distance of approximately two meters (Shabbir, 2020). We can infer from this guidance given by the Prophet (P.B.U.H.) that, in times of pandemics, it is incumbent 
upon Muslims to look after themselves and, more importantly, to protect others from harm. Muslims are aware that the whole earth is the house of Allah (masjid) and this argument gave many congregations reassurance that their prayers would be valid when performed at home and that they would be immeasurably rewarded (Umar, 2020; Drury, 2020). Congregational prayers in normal times involve Muslims standing shoulder to shoulder with one another in the prayer hall, but the Coronavirus pandemic has ended this, due to the introduction of social distancing measures being imposed to drive transmission rates down. In August 2020, the UK Government allowed congregational worship to resume in masjids, but with strict social distancing guidelines. From September 2020, congregational prayers were permitted but many masjids had introduced measures, such as one-way systems for entry and exiting the masjid and the provision of hand sanitiser in the entrances, aimed at reducing exposure to the congregation from Covid-19 (Public Health England, 2020). Local masjid committees marked out each prayer mat on the carpet with tape, to ensure that strict social distancing measures of up to two meters are applied.

\section{Christianity: Teachings in Times of Pandemics}

The Christian faith differs in both theology and practice from Islam in terms of the prescription of actions and rituals. Whilst some Christian traditions today require specific ritual acts, these are few in number. Some holy traditions, such as sacraments, include religious rituals or ceremonies that are regarded as imparting divine grace and the influence of God. Most Protestant church denominations acknowledge only two required religious rites (known as sacraments): these are the Eucharist (also known as Holy Communion) and Baptism. The Roman Catholic Church recognises seven sacraments: Baptism, Eucharist, Confirmation, Anointing of the Sick, Marriage, Holy Orders (Ordination of clergy), and Reconciliation and Penance, which includes Confession and Absolution. The Anglican Church only recognises two sacraments but honors the other five sacraments as important additional sacramental rites. However, those Anglicans who regard the church as Reformed Catholic adhere to the seven Roman Catholic sacraments (Church of England, n.d.). This diversity in acceptance of the holy status of religious rituals demonstrates the breadth of theological perspectives within Christianity that is perhaps not reflected in Islam. The practice and specific rituals of such sacraments may also differ between and even within denominations, and this is deemed to be acceptable today.

There are no prescribed daily rituals that surround Christian worship and prayer. However, some Christian traditions take a more ritualised perspective; for example, Catholics might pray using the Rosary, or attend Mass once a week. Although Catholic adherents might pray the Rosary every day, this is not a requirement and may be viewed almost as superstition or as idolatrous, by some evangelical Protestant Christians. This factor also demonstrates the existence and acceptance of diverse beliefs and practices within Christianity. It is possible to observe a wide range of orthodox practices in shared Christian rituals, such as baptism.

As with previous plagues, epidemics, and pandemics over the past two thousand years, the Coronavirus pandemic has been interpreted by some Christians (though by no means all), as a punishment for sin and idolatry. There are some Christians today who believe that the pandemic is a punishment from God. On the grounds of theology, it can be argued that such a belief is mistaken: firstly because in biblical times, such punishments would have been announced by prophets as the will of God; secondly, the Bible only contains one story about God's punishment of the whole world. Noah's Flood ends with a covenant (or promise) from God that this will never happen again. The evidence for and a reminder of this covenant can be seen in the rainbow. It is evident from science 
that the actions of humankind have contributed to the spread of such viruses from the animal kingdom (Haider et al., 2020).

There are also some Christians today who read the New Testament book of Revelation literally and who argue that the Coronavirus pandemic is therefore a punishment from God, interpreting the current global situation as a sign of the end-times. Food shortages, fear, viruses, and economic collapse are read by some Christians as hints foreshadowing a coming apocalypse. The first episode of The Black Death began in 1347-1353, but the pandemic lasted for over 300 years. Hays suggests that it is possible that, instead of being guided by religious beliefs, "human agency ultimately diverted" this plague. From 1348 when this plague was viewed as "God's visitation" (Hays, 2009, p.54) or punishment on sinful humanity, by the 16th century, actions were being taken to remedy that spread of the virus, as it was finally recognised that it affected all people, no matter what their religious status. It did, however, cause a prolonged economic downturn from the late 1400's onwards (Ibid., 2009).

The Black Death was originally seen as resulting from a "miasma" (Ibid., p.53) or bad air. This idea of corrupt air had an astrological source rather than an orthodox Christian origin (Ibid., 2005, p.53), as mirrored in Islamic perspectives. However, it was eventually recognised that the "occasions that brought towns together" (Ibid., p.54) often resulted in an outbreak or spreading of the disease. These occasions were often church events. Hays explains that responsibility was due to "schools, church services and - especially - the very religious processions that so many towns had sponsored to propitiate God's wrath" (Ibid., pp.54-55). The Christian Flagellant Movement introduced "ritualistic whipping ceremonies" (Aberth, 2011, p.52) that took place during these processions, mainly in Austria, Hungary and Bohemia from 1348-1349 (Ibid.). Past rituals like this find no place in contemporary Christianity.

Another medieval approach to overcoming this plague included what might be considered as "magic" (Hays, 2009, p.87). This invocation of superstitious acts might be combined with religious practices. Hays suggests that "an unclear boundary separated appeals to religion and appeals to magic" (2005, p.55). However, responses of both Muslim and Christian societies to The Black Death was often religious in nature and included the offering of prayers and supplications, and participation in prayer services and processions. More extreme acts included incantations and even exorcisms (Ibid., p.55), but the overall result was to stimulate popular piety throughout Europe and the Near East (Ibid., p.55). Both Christians and Muslims viewed The Black Death is a "product of the will of God" (Ibid., p.53). Christians perceived it as a punishment "for sinful humanity" (Ibid., p.53) that was sometimes general (covering everyone indiscriminately) and sometimes specific (to an individual). The scale of the epidemic meant that it was more often seen as a collective punishment rather than an individual punishment from God. Hays concludes that "Christian attitudes embodied some notion of guilt, perhaps collective, perhaps individual, as an essential explanation of the epidemics" (Ibid., p.53).

Whilst the view that the Black Death or other plagues were "divine punishment for men's sins" (Aberth, 2011, p.52), was common, increasingly, Christian commentators were "far more willing to question God's direct agency and entertain alternative explanations” (Ibid., p.54) for the plague. It was also quite acceptable for Christians to flee from the approaching plague, and indeed, such action was signalled as a Christian virtue (Ibid.). This was in contrast to the advice to Muslims, which advocated that those with the plague stayed where they were, whilst those who were plague-free were enabled to flee. Christian doctors eventually concluded that "God was only one of many possible causes of plague" (Ibid., p.43), and German theologians questioned what the point would be of God sending such a plague (Ibid.). By the 18th century, the church officially supported inoculation (Hays, 2009 , p.123) in its efforts to protect adherents from disease. 
Whilst the 1918-19 influenza pandemic "ranks as the greatest disease event of the $20^{\text {th }}$ century and as one of the most sweeping in the world's history" (Ibid., p.273), influenza has been a widespread viral disease over the past few centuries, as symptoms of the different waves of each pandemic varied in severity. Some influenza pandemics (such as that in 1889-90) were seen almost as benign, even though millions were affected, because "it quietly killed old people" (Ibid., p.274). The influenza pandemic of 1918-19 was most dangerous to young adults and led to some Christians adopting a life of piety and morality in order to avoid infection (Ibid., pp.51-52). Perhaps this could be seen as a precursor to the isolation experienced in lockdown in 2020.

Overall, the impact of Christian cultural memory on pandemics and widespread disease should not be forgotten. The telling and re-telling of the plagues of Egypt and Noah's flood through sermons and religious teaching, to both adults and children, enabled the belief that the Bible could provide "a guide to explain disaster" (Mauelshagen, 2009, p.62). In addition, "disasters reminded Christians to care for the welfare of their immortal souls" (Ibid., p.62), prompting a depth of religious reflection and commitment. Cleanliness was viewed as a health-promoting activity rather than a required religious ritual (Mehfooz et al., 2020), in contrast to the thorough observations of Islam.

\section{Conclusion}

This study considers the messages of revered holy books of both Islam and Christianity in the context of the contemporary COVID-19 pandemic. It recognises the relevance and prescribed rituals, carried out in accordance with these sacred texts and traditions, that aim to preserve people from those diseases that have led to such pandemics in the past. We have considered the impacts of plague and other life-threatening diseases during different time periods of human history on the practices and thinking of people of the Islamic and Christian faiths. Our paper observes that religious teachings can serve as positive and practical guides to humanity in these challenging times.

The religious teachings we have considered are genuinely authentic and worthy of application because, for us, they emanate from the Creator of humanity. We note that that there continue to be scientists, medics, and other scholars who share these common beliefs, affirming that sacred teachings can provide foundations for further advanced research to treat diseases yet unanticipated.

Importantly, we have detected a largely shared belief among the followers of both ancient religions, Christianity and Islam, that divine principles are valid, applicable, and beneficial for those living in this time of the deadly pandemic. These faith traditions accentuate health and well-being. In particular, Islam teaches its followers to adopt a prescribed way of consuming food, as mentioned in Sunnah, which should also be Halal (lawful). The revelation of certain food items in the holy Qur'an strengthens the proposition that fruits, herbs, and plants are helpful remedies for healthy living. Interfaith communities share a common belief that stems from sacred teachings, which could bind them together in hope for the future.

\section{References}

Aberth, J. (2011). Plagues in World History. London: Rowman \& Littlefield.

Abou El-Fadl (1991). 'Law of Duress in Islamic Law and Common Law: A Comparative Study.' Islamic Studies, Vol.30, Issue 3, pp305-350. [Internet] < https://www.jstor.org/stable/20840043> [Accessed 11/08/2020]

Al-Bukharai, M.B. (2003). Sahih Al-Bukhari. Beirut: Dar IbnHazm.

Al-Khalili, J. (2018). Islam and Science: The Language of Science. BBC Four. [Internet] <https://www.bbc.co.uk/programmes/b00gksx4> and <https://youtu.be/4-lHyUYaAIU> [Accessed $7 / 4 / 2020]$

Al-Khalili, J. (2019). The Secret of Quantum Physics: BBC Four. [Internet] < https://www.bbc.co.uk/programmes/ 
b04v5vjz> [Accessed 18/09/2020]

Al-Munajjid, MS. (2009). Description of how to do ghusl for major impurity. Islam Question and Answer. [Internet] $<$ https://islamqa.info/en/answers/82344/description-of-how-to-do-ghusl-for-major-impurity> [Accessed 25/08/2020]

Alsalabi, Ali Muhammad. (2005). Sirat Amir Almuminin Umar bin alKhattab shakhsiatuhu waasrahu. Cairo: Iqra.

Aslan, R.S (2020) Wudu and coronavirus: Islamic ritual washing may help spread a good hygiene message. Medical Express.com [Internet] < https://medicalxpress.com/news/2020-03-wudu-coronavirus-islamic-ritual-good. html $>$ [Accessed 25/08/2020]

AzIslam.org (2020). Patience in Islam. AzIslam.org. [Internet] < https://azislam.com/patience-in-islam> [Accessed $11 / 08 / 2020]$

Bamosa, A., Kaatabi, H., Lebdaa, F. (2010). Effect of Nigella sativa seeds on the glycemic control of patients with type 2 diabetes mellitus. Indian J Physiol Pharmacol 54 (4) 344-54. [Internet] <https://pubmed.ncbi.nlm.nih.gov/21675032/> [Accessed 24/08/2020]

Bell, D.P. (2019). Plague in the Early Modern World: A Documentary History. London: Routledge.

Blanchard, P. (2020). 'Trevor Phillips asks whether lack of Muslims in England's coronavirus hotspots may be down to their rigorous hand-washing practice five times a day.' Daily Mail. [Internet] $<$ https://www.dailymail.co.uk/news/article-8236303/Ethnic-minority-areas-make-three-quarters-Englandscoronavirus-hotspots.html> [Accessed 25/08/2020]

Bradford, A. (2015). Mediterranean Diet: Foods, Benefits \& Risks. Live Science.com. [Internet] < https://www. livescience. com/52832-mediterranean-diet.html> [Accessed 21/08/2020]

Bulaqteeb. A. (2002). Jawayih wa'awbiat maghrib ahid almuahadin. Morocco: Manshorat Alzaman.

Burton, J (1988). The Qur'an and the Practice of Wudu. Bulletin of the School of African and Oriental Studies, University of London Vol.51, (1), pp21-58. JSTOR [Internet] < https://www.jstor.org/stable/618666?seq=1\# metadata_info_tab_contents> [Accessed 25/08/2020).

Carraher, W. and Pettegrew, D.K. (2019). The Archaeology of Early Christianity: The History, Methods, and State of a Field. In: Caraher, W.R., Davis, T.W. \& Pettegrew, D.K. (2019) The Oxford Handbook of Early Christian Archaeology. [Internet] <https://www.oxfordhandbooks.com/view/10.1093/oxfordhb/9780199369041.001. 0001/oxfordhb-9780199369041-e-1> [Accessed 18/08/2020]

Cheng, Y. (2020, April 3). 'Of the Virus and God, Orange Peels and the Party.' The New York Times. $<$ https://www.nytimes.com/2020/04/03/opinion/sunday/coronavirus-china-US.html>[Accessed 31/03/ 2020]

Coogan, M.D. (Ed.) (2007). The New Oxford Annotated Bible. Translation: New Revised Standard Version (NRSV). Augmented 3rd Ed. Oxford: Oxford University Press.

Diabetes UK (2020) Updates: Coronavirus and Diabetes. Diabetes UK. [nternet] < https://www.diabetes.org.uk/ about_us/news/coronavirus> [Accessed 22/08/2020]

DiRenzo, L., Gualtieri P., and Pivari, F. (2020). Eating habits and lifestyle changes during COVID-19 lockdown: an Italian survey. Journal of Translational Medicine 18,229. [Internet] <https://translational-medicine. biomedcentral.com/articles/10.1186/s12967-020-02399-5\#citeas> Accessed 21/08/2020).

Drury, C. (2020). 'A joy to be back: Places of worship reopen for private prayer three months after coronavirus lockdown.' The Independent. [Internet] < https://www.independent.co.uk/news/uk/home-news/coronaviruschurch-mosque-temple-reopen-lockdown-wedding-a9567316.html $>$ [Accessed 30/08/2020]

Echenberg, M. (2011). Africa in the Time of Cholera: A History of Pandemics from 1817 to the Present. Cambridge: Cambridge University Press.

Edriss, H., Brittany N. Rosales, N. B., Nugent, C., Conrad, C., and Nugent, K., (2017). Islamic Medicine in the Middle Ages: The History of Medicine, 354 (3), pp.223-229.

Elias, A.A. (2020). Hadith on Harm: There is no harm, reciprocating harm. Daily Hadith Online. [Internet] <https://abuaminaelias.com/dailyhadithonline/2016/08/15/la-darara-wa-la-dirar/> [Accessed 11/08/2020]

Elsanousi, M, Roberts, B, Visotzky, B.L (2020). World Economic Forum. Love your neighbour: Islam, Judaism and Christianity come together over COVID-19 [Internet] < https://www.weforum.org/agenda/2020/04/religionsCovid-19-coronavirus-collaboration/> [Accessed 10/08/2020]

Ewing, E.T. (2017). 'Will it come here? Using Digital Humanities Tools to Explore Medical Understanding During the Russian Flu Epidemic, 1889-90.' Medical History. Vol.61, pp474-477.

Farhangi, H., Ajilian,M., Saeidi, M., Khodaei, GH. (2014). Medicinal Fruits in Holy Qur'an. International Journal of Pediatrics (Supplement 4), Vol.2, N.3-2, Serial No.8. [Internet] <http://ijp.mums.ac.ir/article_3461_f3d52c77 


\section{A Discussion of Relevant Religious Teachings from Islam and Christianity to the COVID-19 Crisis}

bcdf325842a9c01c60d329cc.pdf> [Accessed 22/08/2020]

Farris, W.W. (1985). Population, Disease, and Land in Early Japan, 645-900. Harvard.

Fox, A, Feng, W, Asal, V. (2019). What is driving global obesity trends: Globalization or 'Modernisation'? Biomedical Central.org. [Internet] <https://globalizationandhealth.biomedcentral.com/articles/10.1186/s12992-019-0457y> [Accessed 21/08/2020]

Gali-Muhtasib, H., El-Najjar,N., Schneider-Stock, R. (2006). The medicinal potential of black seed (Nigella sativa) and its components. Science Direct.com [Internet] <https://www.sciencedirect.com/science/article/pii/S1572 557X05020088> [Accessed 24/08/2020]

Gaythorpe K., Imai N., Cuomo-Dannenburg G., Baguelin, M., Bhatia, S., Boonyasiri, A., Cori, A., Cucunubá, Z., Dighe, A., Dorigatti, I., FitzJohn, R., Fu, H., Green, W., Hamlet, A., Hinsley, W., Laydon, D., Nedjati-Gilani, G., Okell, L., Riley, S., Thompson, H., Sabine van Elsland, Volz, E., Wang, H., Wang, Y., Whittaker, C., Xi, X., Donnelly, C.A., Ghani, A., and Ferguson, N.M. (2020). Report 8: Symptom progression of 2019 novel coronavirus. [Internet]: https://www. imperial. ac.uk/ media/imperial-college/medicine/sph/ide/ gidafellowships/Imperial-College-COVID19-symptom-progression-11-03-2020.pdf [Accessed 21/08/2020]

Ghaffar, R. (2018). 'Olive Health Benefits According to Qur'an and Hadith.' Islamic Finder.org. [Internet] $<$ https://www.islamicfinder.org/news/olive-health-benefits-according-to-quran-and-hadith/> Accessed 21/ 08/2020]

Goodhew, D. (ed.) (2012). Church Growth in Britain: 1980 to the Present. Farnham: Ashgate Publishing.

Gottfried, R.S. (1983). The Black Death: Natural and human disaster in Medieval Europe. New York: Free Press.

Guntzelman, J. (2011) Turning to God in Tough Times: Prayers to Comfort the Heart and Sustain the Spirit. Maryland: The Word Among Us Press.

Haider, N., Rothman-Ostrow, P., Osman, A.Y., Arruda, L.B., Macfarlane-Berry, L., Elton, L., Thomason, M.J., Yeboah-Manu, D., Ansumana, R., Kapata, N., Mboera, L, Rushton, J., McHugh, T.D., Heymann, D.L., Zumla, A. and Kock, R.A. (2020). 'COVID-19-Zoonosis or Emerging Infectious Disease?' Frontiers in Public Health. Vol.8 [Internet] <https://www.frontiersin.org/article/10.3389/fpubh.2020.596944> [Accessed 28/04/2021]

Hakim, S. (2016). 'The Paths to God'. Journal of the Muhyiddin Ibn Arabi Society. Vol.59 [Internet] $<$ https://ibnarabisociety.org/the-paths-to-god-souad-hakim/> [Accessed 29/04/2021]

Harper, K. (2015). Pandemics and Passages to late antiquity: rethinking the plague of c249-270 described by Cyprian. Journal of Roman Archaeology. Vol. 28 (2015)

Hatanaka, M, Caporuscio, J. (2020). Can figs be beneficial to our health. Medical News Today. [Internet] $<$ https://www.medicalnewstoday.com/articles/327207> [Accessed 22/08/2020]

Hays, J.N. (2005). Epidemics and Pandemics: their impacts on human history. Santa Barbara, CA: ABC Clio.

Hays, J.N. (2009). The Burdens of Disease: Epidemics and Human Response in Western History. (Revised Ed.) New Brunswick, NJ: Rutgers University Press.

He, D., Dushoff, J., Day, T., Ma J. \& Earn D.J.D. (2013). Inferring the causes of the three waves of the 1918 influenza pandemic in England and Wales. Proc. R. Soc. B.28020131345 [Internet] < https://royalsocietypublishing.org/ doi/full/10.1098/rspb.2013.1345> [Accessed 21/08/2020]

Hindson, Ed, (1999). God is There in the Tough Times: Turning Your Disappointments into Hope: Oregon: Harvest House Publishers.

Honigsbaum, Mark. (2013). A History of the great influenza pandemics: death, panic and hysteria, 1830-1920. London: I.B. Tauris

Hrynowski, Z. (2019, November 8). How Many Americans Believe in God? Gallup. [Internet] <https://news.gallup.com/poll/268205/americans-believe-god.aspx> [Accessed 1/04/2020]

Ibn Kathir. (2010). Al-Bidaya wa-n-Nihaya. Cairo: Dar Ibn Algawzi.

Ibn Khaldun. (1989). The Muqaddimah: An Introduction to History. Translated by Franz Rosenthal. London: Princeton University Press

Jones, B. (2015). 'Is it any wonder religion is on the wane?' The Guardian, 12 February 2015. [Internet] < https://www.theguardian.com/commentisfree/2015/feb/12/religion-atheism-britons-god> [Accessed 3/04/ 2020]

Kelly, N., Rees, B., Shuter, P. (2002). Medicine Through Time: Oxford: Heinemann Education Institute.

Khan, T.A (2019) Honey: A Cure for Mankind? Al Hakam.org. [Internet] < https:/ /www.alhakam.org/honey-a-curefor-mankind/> [Accessed 23/08/2020]

Khanna M, Gupta N, Gupta A and Vijayan V K. (2009). Influenza A (H1N1) 2009: a pandemic alarm; J. Biosci. 34 481-489] 
Kola, L. (2020). 'Global Mental Health and Covid19.' The Lancet Psychiatry. [Internet] < https://www.thelancet. com/journals/lanpsy/article/PIIS2215-0366(20)30235-2/fulltext> [Accessed 11/08/2020]

Kwok, Y.L., Gralton, J. and McLaws, M.L. (2015). Face touching: a frequent habit that has implications for hand hygiene. American Journal for Infection Control. 2015 Feb;43(2):112-4. doi:10.1016/j.ajic.2014.10.015 [Internet] $<$ https://pubmed.ncbi.nlm.nih.gov/25637115/> [Accessed 28/04/2021]

Lipka, M. and Hackett, C. (2017). 'Why Muslims are the world's fastest-growing religious group.' PEW Research. 6 April 2017 [nternet] <https://www.pewresearch.org/fact-tank/2017/04/06/why-muslims-are-the-worldsfastest-growing-religious-group/> [Accessed on 5/04/ 2020]

Mauelshagen, F. (2009). 'Disaster and Political Culture in Germany since 1500'. In: Mauch, C. \& Pfister, C. (Eds.,) (2009) Natural Disasters, Cultural Responses: Case Studies toward a Global Environmental History. Plymouth: Rowman \& Littlefield.

Mehfooz, M., Badshah, S.N. and Zada, N. (2020). 'History of Contagious Disease Outbreaks during Early Muslim Empire: Understanding the Impact of Islamic Principles'. Al-Azhaar. Vol 6. Issue 1, Jan-June 2020 [Internet] $<$ http://al-azhaar.org/ojs/index.php/rj/issue/view/12> [Accessed 18/08/2020]

Mohamed, N. (2017). Plants of the Qur'an. About Islam. [nternet] <https://aboutislam.net/muslim-issues/sciencemuslim-issues/plants-of-the-quran-part-ii-olives/> [Accessed 18/08/2020]

Morrison, O. (2020). Spanish Consumers shifted to healthier diets during COVID 19 confinement-study. Food Navigator.com. [nternet] <https://www.foodnavigator.com/Article/2020/06/16/Spanish-consumers-shiftedto-healthier-diets-during-COVID-19-confinement-study> [Accessed 21/08/2020]

Perkins, T. (2020). 'The power of prayer to deal with coronavirus anxiety.' USA Today 12 March, 2020. [Internet] $<$ https://eu.usatoday.com/story/opinion/2020/03/12/power-prayer-deal-reduce-coronavirus-anxiety-Covid19-column/5014472002/> [Accessed on 5/05/2020]

Peterson, D.C, (2020). Islamic Guidelines on Covid19 (Coronavirus). Patheos.com. [Internet] <https://www. patheos.com/blogs/danpeterson/2020/03/islamic-guidelines-on-Covid-19-coronavirus.html> [Accessed 10/08/2020]

PEW Research (2014). 'Worldwide, Many See Belief in God as Essential to Morality: Richer Nations Are Exception: A Survey Report.' Pew Research, 13 March 2014. [Internet] < https://www.pewresearch.org/global/2014/03/ 13/worldwide-many-see-belief-in-god-as-essential-to-morality/> [Accessed on 5/05/2020]

Phillips, D., Curtice, J., Phillips, M. and Perry, J. (eds.) (2018). British Social Attitudes: The 35th Report, London: The National Centre for Social Research. [Internet] <https://www.bsa.natcen.ac.uk/media/39284/bsa35_fullreport.pdf> [Accessed 12/04/2020]

Public Health England (2020). 'Staying Safe for Eid Ul-Adha.' Public Health England. [Internet] <https://publichealthmatters.blog.gov.uk/2020/07/24/staying-safe-for-eid-al-adha/> [Accessed 30/08/2020]

Raleigh, V. (2020). 'Deaths from Covid19 (Coronavirus): how are they counted and what do they show.' The Kings Fund. [Internet] < https://www.kingsfund.org.uk/publications/deaths-Covid-19> [Accessed 19/08/2020]

Ribero, C. (2020). 'The ground's been ripped from under them': mental health fears for the children of the pandemic. The Guardian. [Internet] <https://www.theguardian.com/world/2020/aug/08/the-grounds-been-rippedfrom-under-them-mental-health-fears-for-the-children-of-the-pandemic > [Accessed 10/08/2020]

Rigby, S. (2020). 'Coronavirus: Is hand-washing really the best thing we can do to stop the spread of COVID-19?' Science Focus.com. [Internet] <https://www.sciencefocus.com/news/coronavirus-can-hand-washing-reallystop-the-spread-of-Covid-19/> [Accessed 25/08/2020]

Rouhani, M.H, \& Azadbakht, L (2014). Is Ramadan fasting related to health outcomes? A review on the related evidence. Journal of Research and Medical Sciences, 19:10, 987-992. [Internet] <https://www.ncbi.nlm.nih. gov/pmc/articles/PMC4274578> [Accessed 11/08/2020]

Saged, A.A.G., Mohd Yusoff, M.Y.Z., Abdul Latif, F. Hilmi, S.M., Al-Rahmi, W.M., Al-Samman, A., Alias, N. \& Zeki, A.M. (2020). Impact of Quran in Treatment of the Psychological Disorder and Spiritual Illness. Journal of Religious Health. Vol. 59, pp1824-1837. [Internet] <https://doi.org/10.1007/s10943-018-0572-8> [Accessed $25 / 08 / 2020]$

Shabbir, Y. (2020). Social Distancing Hadith Authenticity. Islamic Portal. [Internet] <https://islamicportal. co.uk/social-distancing-hadith-authenticity/> [Accessed 26/08/2020]

Shah, M.A. \& Salam, H.A. (2020). 'Ablution might have cut virus risk in UK Muslims: report, Geo News.' The News. [Internet] <https://www.thenews.com.pk/print/648432-ablution-might-have-cut-virus-risk-in-uk-muslimsreport> [Accessed 25/08/2020] 


\section{A Discussion of Relevant Religious Teachings from Islam and Christianity to the COVID-19 Crisis}

Sofuoglu, M. (2020). Could Islam's emphasis on hygiene make a difference in a pandemic? TRT World. [Internet] $<$ https://www.trtworld.com/magazine/could-islam-s-emphasis-on-hygiene-make-a-difference-in-a-pandemic35469> [Accessed 25/08/2020]

Stacey, A. (2018). Chapter 95 Al-Teen (The Fig). The Religion of Islam. [nternet] < https://www.islamreligion. com/articles/11346/chapter-95-at-teen-fig/> [Accessed 19/08/2020]

Sweet, K. (2014). The Unwelcome traveler: England's Black Death and Hopi’s Smallpox. Unpublished PhD thesis. Phoenix, AR: Arizona State University.

Tabri. (1967). Tarikh al-Rusul wa al-Muluk. Cairo: Dar Almaarif.

Tamir, C., Connaughton, A., and Salazar, M.A. (2020). The Global God Divide: Pew Research, [Internet] <https://www.pewresearch.org/global/2020/07/20/the-global-god-divide/> [Accessed on 13/09/2020].

Trimble, M. and Austin, S. (2020). 'The 10 Most Religious Countries, Ranked by Perception.' US News 15 January 2020 [Internet] <https://www.usnews.com/news/best-countries/articles/10-most-religious-countries-rankedby-perception> [Accessed 5/05/2020]

Umar, M. (2020). Islamic Guidance Pertaining to the Spread of Covid-19 [Coronavirus. California Islamic University. [Internet] <https://www.calislamic.com/islamic-guidance-pertaining-to-the-spread-of-Covid-19-coronavirus/> [Accessed 26/08/2020]

Waqidi, M.I.U. (2004). Kitab al-Maghazi (2 v.). Bayrut : Dar al-Kutub al-Ilmiyah.

Wong, C. (2020). 'The Health Benefits of Black Seed Oil.' Very Well Health.com [Internet] <https://www. verywellhealth. com/health-benefits-of-black-seed-oil-89421> [Accessed 24/08/2020]

World Health Organisation (2020). Coronavirus disease (COVID-19) advice for the public. World Health Organisation. [Internet] <https://www.who.int/emergencies/diseases/novel-coronavirus-2019/advice-forpublic> [Accessed 26/08/2020]

World Health Organisation (2020). 'Coronavirus disease (COVID-19) pandemic.' World Health Organisation. September 21, 2020 [Internet] <https://www.who.int/emergencies/diseases/novel-coronavirus-2019> [Accessed 20/09/2020]

World Health Organisation (2020). 'Transmission of SARS-CoV-2: implications for infection prevention precautions.' World Health Organisation. [Internet] < https://www.who.int/news-room/commentaries/detail/ transmission-of-sars-cov-2-implications-for-infection-prevention-precautions $>$ [Accessed 25/08/2020]

Worldometers $(2020,2021)$ Coronavirus. [Internet] <https://www.worldometers.info/coronavirus/> [Accessed 30/08/2020; 28/04/2021]

Yimer, E.M., Tuem, K.B. and Karim., A. (2019). 'Nigella sativa L. (Black Cumin): A Promising Natural Remedy for Wide Range of Illnesses.' Hindawi, Evidence based complementary alternative medicine. [Internet] <https://www.ncbi.nlm.nih.gov/pmc/articles/PMC6535880/> [Accessed 24/08/2020] 